\title{
Effect of exogenous somatotropin and staged ovariectomy on mRNA expression of select ECM-related proteins in mammary tissue of prepubertal Holstein calves
}

\author{
Brandy Patrice Huderson ${ }^{1}$, Bisi Thankamani Velayudhan ${ }^{1}$, Ronald Edward Pearson ${ }^{1}$, \\ Steve Edward Ellis ${ }^{2}$, Robert Michael Akers ${ }^{1^{*}}$ \\ ${ }^{1}$ Department of Dairy Science, Virginia Polytechnic Institute and State University, Blacksburg, USA; \\ *Corresponding Author: rma@,vt.edu \\ ${ }^{2}$ Department of Animal and Veterinary Sciences, Clemson University, Clemson, USA \\ Received 29 March 2013; revised 15 May 2013; accepted 15 June 2013 \\ Copyright (C) 2013 Brandy Patrice Huderson et al. This is an open access article distributed under the Creative Commons Attribution \\ License, which permits unrestricted use, distribution, and reproduction in any medium, provided the original work is properly cited.
}

\begin{abstract}
Growth hormone (GH) and estrogen are essential stimulators of mammary cell proliferation and mammary development as mammals near puberty. Mammary ductal growth requires modifications of the extracellular matrix (ECM) for this tissue expansion to occur. Our purpose was to evaluate the effects of exogenous $\mathrm{GH}$ and ovariectomy (known to impact estrogen production) on gene expression of selected ECM proteins in the mammary parenchyma (PAR) and mammary fat pad (MFP) of prepubertal calves. Our hypothesis was that both GH and ovariectomy would alter the mRNA expression of multiple mammary ECM proteins. However, treatment with GH significantly reduced the expression of only fibronectin in PAR. However, the mRNA expression of all of the ECM proteins tested was numerically lower in PAR from GH treated calves. In contrast, staged ovariectomy decreased expression of fibronectin and heat shock protein 90 but increased expression of epimorphin in mammary PAR. In the MFP expression of Rac-1 and fascin were increased. These findings suggest that effects of exogenous GH on mammary gland composition are only marginally dependent on alterations in ECM proteins but the more pronounced effects of ovariectomy (reduced PAR mass and altered myoepithelial ontogeny) are more likely linked to changes in expression of ECM proteins.
\end{abstract}

Keywords: Bovine Mammary Development; Gene
Expression; Extracellular Matrix; Growth Hormone; Ovariectomy

\section{INTRODUCTION}

It is nearly impossible to discuss mammary ductal growth and development without considering the classic mammogenic hormones estrogen (E) and growth hormone (GH) [1]. Despite the well-established importance of these hormones in bovine mammogenesis, understanding how these hormones impact expression of extracellular matrix (ECM) proteins of the prepubertal bovine mammary gland is unexplored. We took advantage of tissues collected from recent experiments which determined the effect of exogenous GH (Huderson et al. [2]) and staged ovariectomy (Velayudhan et al. [3]) on mammary development, to provide samples for this evaluation. Details on treatments, animal handling, and overall mammary development are available in these references.

It is reported that GH's mammogenic effects may be mediated through IGF-I rather than direct stimulation via GH [4]. However, other studies $[5,6]$ demonstrate the presence of both GH receptor (GHR) mRNA and receptor protein in bovine mammary tissue. This suggests the likelihood of direct effects of GH as well as effects attributed to IGF-I, its receptors and associated binding proteins $[7,8]$. Furthermore, estrogen administration increases ductal cell proliferation and the expression of IGF-I mRNA and IGF-I in the mammary gland [9-11]. Capuco et al. [12] reported that in prepubertal bovine mammary gland, epithelial cells which express estrogen receptor are not the same cells that proliferate in respon- 
se to administration of exogenous estradiol. Thus many of the mammogenic effects attributed to both GH and E are likely mediated by intermediate signaling molecules.

At birth, the ruminant mammary gland is composed of rudimentary ducts surrounded by stroma (STR) and more distant mammary fat pad (MFP). Between 1.5 to 3 months of age the mammary gland enters a phase of allometric growth characterized by extensive invasion of the STR and MFP by proliferating mammary ducts $[13,14]$. The STR, which consists of fibroblasts, preadipocytes and ECM, is actively remodeled and degraded. The ECM was initially viewed as simply a structural support for cell attachment. But it is now known that the ECM acts to mediate cell proliferation, cell migration, and ductal morphogenesis in both normal mammary development and in mammary cancer $[15,16]$. For example in rodent and human cell culture models, changes in the ECM modulate mammary cell response to growth factors and hormones [16,17]. The ECM proteins also regulate expression of insulin-like growth factor-I receptor, epidermal growth factor receptor and concentrations of IGF-I binding proteins in mammary tissue [16]. Berry et al. [18] showed localization of key ECM proteins within the bovine mammary gland and suggested roles for each in regulating mammary gland development. Others [19] have surveyed gene expression of proteins involved in ECM degradation in bovine mammary tissue from older animals and especially changes in gene expression in parenchyma and stroma just before and after calving [20]. But to our knowledge there are no reported data for ECM gene expression in the mammary tissue of prepubertal calves. Despite advancements in understanding of the role of the ECM in mammary development generally, mechanisms remain unclear. Extensive work employing cell culture has provided many specific biochemical details but little related to in vivo responses. However, the idea of cross-talk between the ECM and/or MFP and the developing epithelium is widely supported [21-23]. Thus our interest in ECM is well justified.

In the current study we examined modifications in the mRNA expression of ECM proteins after treatment with exogenous GH and after ovariectomy (OVX). We hypothesized that the administration of exogenous $\mathrm{GH}$, which is known to be involved in mammogenesis in the bovine, would correspond with modified expression of selected ECM-related genes in both the PAR and the surrounding MFP. We further hypothesized that ovariectomy which is known to impair peripubertal mammary development, would also alter expression of ECM-related genes in the developing mammary gland.

\section{MATERIALS AND METHODS}

\subsection{Animals and Tissue Harvesting}

All tissues used for these experiments were collected from two animal studies. In a first experiment, Huderson et al. [2], 19 Holstein heifer calves were randomly assigned to either Posilac (bST; $500 \mathrm{mg}$ of bST; $\mathrm{n}=10$; Monsanto Co., St Louis, MO) or Placebo (Sal; 0.9\% saline; $n=9$ ) treatment (Figure 1). Within treatment animals were assigned to an early (E) or late (L) harvest point. Treatments were initiated on d 23 of age and repeated every $21 \mathrm{~d}$ thereafter via subcutaneous injections. Animals in the early harvest group received two injections and were sacrificed $21 \mathrm{~d}$ after the second injection. Animals in the late harvest group received four injections and were harvested $21 \mathrm{~d}$ after the fourth injection. One heifer was dropped from the study after harvest due to chronic illness. In a second experiment, Velayudhan et al. [3], 20 Holstein heifer calves were randomly assigned to one of two treatments, ovariectomy (OVX; $\mathrm{n}=8$ ) or sham operation (INT; $\mathrm{n}=12$ ) (Figure 2). Surgeries were performed at 2, 3 and 4 months of age. Thirty days after each respective surgery, mammary gland tissue was harvested.

At the time of sacrifice mammary glands were imme-

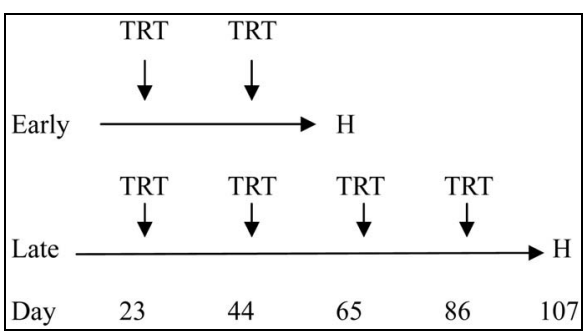

Figure 1. Experimental design for heifers treated with bST and Sal. Heifers were randomly assigned at birth to one of two treatments (TRT), Posilac (bST; $500 \mathrm{mg}$ of BST; $\mathrm{n}$ $=10)$ or Placebo $(\mathrm{Sal} ; 0.9 \%$ saline; $\mathrm{n}=9)$. Heifers were then assigned to either an early (E) or late (L) tissue harvesting group. Animals in the $\mathrm{E}$ group received two injections (vertical arrows) and tissue was harvested 21 $\mathrm{d}$ later $(\mathrm{H})$. Animals in the L harvest group received four injections (vertical arrows) and tissue harvested $(\mathrm{H}) 21 \mathrm{~d}$ later.

\begin{tabular}{|llllllll|}
\hline Surgery: & \multicolumn{1}{c|}{$\mathrm{O} / \mathrm{S} \mathrm{O} / \mathrm{S} \mathrm{O} / \mathrm{S}$} \\
& & & & & & & \\
Age (mo.) & 0 & 1 & 2 & 3 & 4 & 5 \\
\hline
\end{tabular}

Figure 2. Experimental design for OVX or INT heifers. Heifers were randomly assigned to one of two treatments, ovariectomy (OVX; $\mathrm{n}=8$ ) or sham operation (INT; $\mathrm{n}=12$ ). Surgeries were performed at 2-, 3- and 4- mo. Mammary tissue was harvested 30d after treatment was applied. $\mathrm{O} / \mathrm{S}$ indicate animals were ovariectomized $(\mathrm{O})$ or sham operated $(\mathrm{S})$ at the indicated time periods. 
diately removed. Glands were bisected along the medial suspensory ligament and one udder half was immediately snap-frozen. Parenchyma and MFP were dissected from the remaining glands. Tissue samples were snap-frozen and stored at $-80^{\circ} \mathrm{C}$.

\subsection{RNA Extraction and Reverse Transcription}

Tissue samples were homogenized in TRI reagent (Molecular Research Center, Inc., Cincinnati, OH). Homogenates were separated into phases using chloroform. Isopropanol was added to the aqueous phase to precipitate RNA. Precipitated RNA was ethanol washed (75\% in RNase free water) and the resulting pellet air dried and suspended in diethyl pyrocarbonate (Sigma-Aldrich, St. Louis, MO) treated water. Concentration and purity of extracted RNA were determined using a Nanodrop ND-1000 Spectrophotometer (Nanodrop Technologies Inc., Wilmington, DE). Single stranded cDNA was re- verse transcribed from total RNA using a High Capacity cDNA Reverse Transcription Kit (Applied Biosystem, Foster City, CA). Briefly, $20 \mu \mathrm{g}$ of RNA was reverse transcribed in reaction with a final volume of $20 \mu \mathrm{l}$ using random primers and $0.02 \mathrm{U}$ of Rnase inhibitor. Resulting cDNA was diluted 1:10 and used in quantitative real time PCR reactions.

\subsection{Quantitative Real Time PCR}

Quantitative real-time PCR was performed on 13 target genes (Table 1). With the exception of collagen I (Col I) and fibronectin (FN) all primers were designed using GenBank sequences. Published primer sequences were used for Col I and FN. All primers were designed against the corresponding bovine gene. Two microliters of diluted cDNA was combined with $12.5 \mu \mathrm{L}$ of SYBR Green dye (Applied Biosystems, Foster City, CA), 9.5 $\mu \mathrm{L}$ of sterile distilled water, $0.5 \mu \mathrm{L}$ of $10 \mu \mathrm{M}$ of both forward and reverse primers. Real time PCR conditions

Table 1. Primer sequences for ECM-related genes.

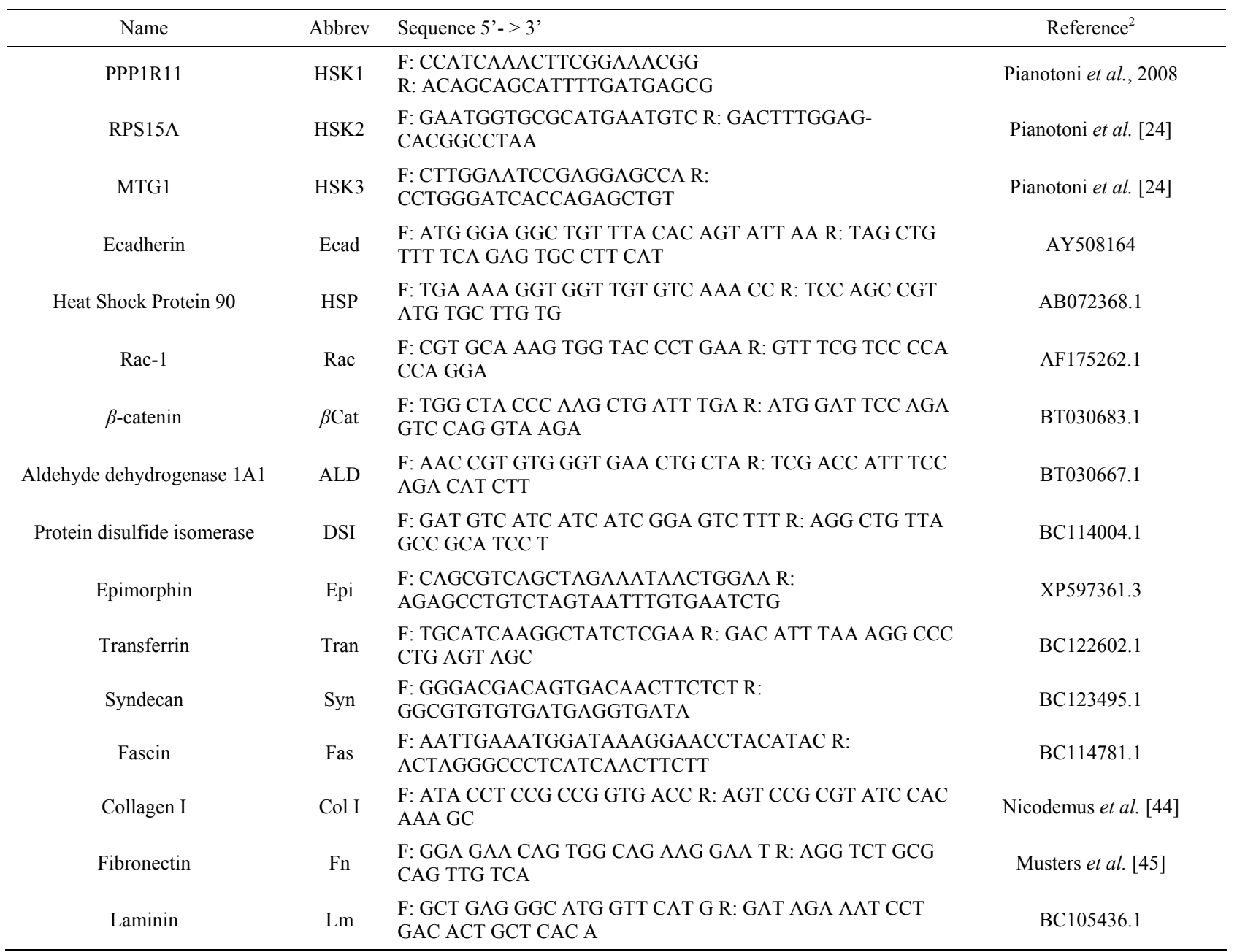

${ }^{1}$ Genes were selected using bovine genes and primers were designed using Primer Express Software 3.0. ${ }^{2}$ Refers to published paper or Pubmed Accession number. 
were activation of DNA polymerase at $95^{\circ} \mathrm{C}$ for $10 \mathrm{~min}$, denaturation at $95^{\circ} \mathrm{C}$ for $15 \mathrm{~s}$, and annealing/extension at $60^{\circ} \mathrm{C}$ for $1 \mathrm{~min}$ and the sequence was repeated for 40 cycles (Applied Bio systems). Real-time PCR reactions were performed in a 7300 Series Real-Time System and the data were collected and analyzed using SDS software (Applied Biosystems, Foster City, CA). Cycle thresholds $(\mathrm{Ct})$ values of genes of interest were normalized $(\Delta \mathrm{Ct})$ using the geometric mean of three endogenous reference genes: PPP1R11 (HSK1; forward, 5'-CCAT-CAAACTTCGGAAACGG-3'; reverse 5'-ACAGCAGCATTTTGATGAGCG-3'), RPS15A (HSK2; forward, 5'-GAATGGTGCGCATGAATGTC-3'; reverse, 5'-GACTTTGGAGCACGGCCTAA-3') and MTG1 (HSK3; forward, 5'CTTGGAATCCGAGGAGCCA-3'; reverse, 5'-CCTGGGATCACCAGAGCTGT-3') [24] (Table 1). Primers were designed using Primer Express Software 3.0 (Applied Biosystems, Foster City, CA) and purchased from integrated DNA Technologies (Coralville, IA). All primers were diluted to $10 \mu \mathrm{M}$ in RNase/DNase free water. Efficiency of endogenous reference genes and target genes was tested using five dilutions of cDNA in duplicate. Target genes were: ecadherin (Ecad), heat shock protein 90 (HSP), Rac-1 (Rac), $\beta$-catenin ( $\beta$ Cat), aldehyde dehydrogenase 1A1 (ALD), protein disulfide isomerase (DSI), epimorphin (Epi), transferrin (Tran), syndecan (Syn), fascin (Fas), collagen I (Col), fibronectin (FN), and laminin (LN). Data was expressed as fold difference, calculated as $\left(2^{(-\Delta \Delta \mathrm{Ct})}\right)$. Additionally, dissociation curves were run on all samples to detect primer dimers, contamination or presence of other amplicons.

\subsection{Statistics}

All data were analyzed using the Mixed Procedure of SAS (Version 9.2 SAS Institute Inc., Cary, NC). Pairwise comparisons were carried out using the Tukey test. The main effects of treatment, group (for experiment one, E or L; for experiment two, age at surgery), and the interaction between the two were analyzed. The statistical model statement is as follows.

$$
\mathrm{Y}_{\mathrm{ijk}}=\mu+\mathrm{T}_{\mathrm{i}}+\mathrm{G}_{\mathrm{j}}+(\mathrm{TG})_{\mathrm{ij}}+\mathrm{e}_{(\mathrm{ijk})}
$$

where $Y_{i j k}$ is the variable being tested, $\mu$ is the overall mean; $\mathrm{T}_{\mathrm{i}}$ is the fixed effect of treatment (bST vs. Placebo; $\mathrm{i}=1,2)$ or (OVX vs. INT; $\mathrm{j}=1,2) ; \mathrm{G}_{\mathrm{j}}$ is the fixed effect of harvest group (Early vs. Late; $\mathrm{j}=1,2$ ) or (age at surgery; $\mathrm{j}=1,2,3 \mathrm{mo})$; $(\mathrm{TG})_{\mathrm{ij}}$ is the effect of the interaction between treatment and group and $\mathrm{e}_{(\mathrm{ijk})}$ is the residual error (assumed to be normally and independently distributed).

Graphical representation of gene expression data is given as treatment relative to control animals $2^{(-\Delta \Delta \mathrm{Ct})}$. The $\Delta \Delta \mathrm{Ct}$ was calculated as the $\Delta \mathrm{Ct}$ of treatment minus the $\Delta \mathrm{Ct}$ of control. Results are presented as least squares means \pm standard error of the means and declared sig- nificant at $\mathrm{P} \leq 0.05$.

\section{RESULTS}

\subsection{Effect of bST on Transcript Abundance}

In PAR the expression of all genes tested was numerically lower in bST treated heifers but only the expression of FN was significantly reduced compared with saline treated heifers $(\mathrm{P}=0.04)$ (Figure 3(a)). In MFP, bST had no significant effect on gene expression (Figure 3(b)), with some genes numerically greater and some lower than in control animals. Regarding the effect of time of sampling, in PAR, expression of Tran was reduced $(\mathrm{P}=$ 0.04 ) in the older heifers irrespective of treatment. In MFP, expression of DSI in bST treated heifers was greater compared with Sal in heifers in the early E group $(\mathrm{P}=0.01)$ but not in the older animals $(\mathrm{P}>0.05)$. Expression of Syn was increased $(\mathrm{P}=0.05)$ with age $(\mathrm{L}$ harvest $>$ that $\mathrm{E}$ harvest) in control heifers. No other genes tested were affected by harvest group nor was there an interaction between treatment and harvest group.

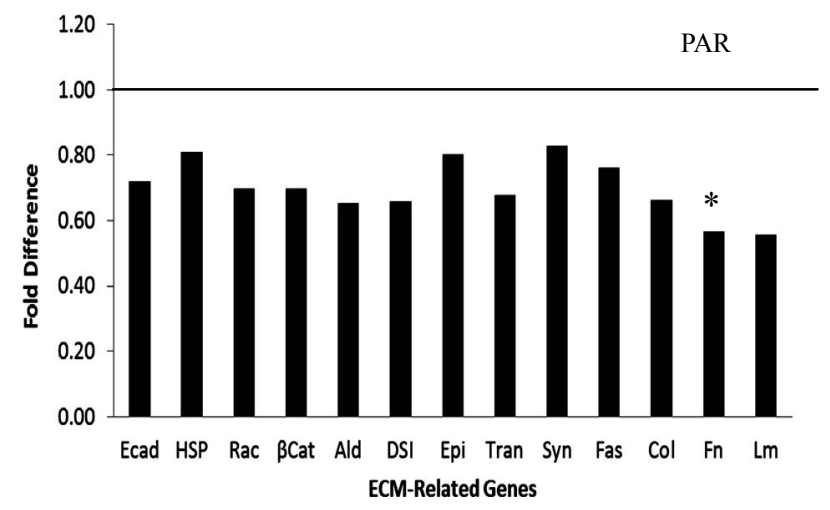

(a)

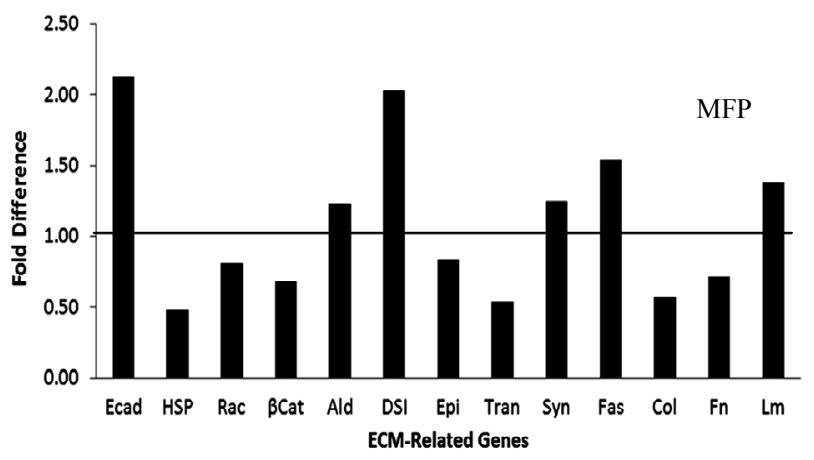

(b)

Figure 3. Gene expression for ECM-related genes in bST and Sal treated heifers. Gene expression for ECM-related genes for bST treated heifers relative to Sal treated heifers (represented by solid line at 1.00). Panel A provides data for parenchymal (PAR) tissue and panel B data for mammary fat pad (MFP). Asterisks $(*)$ indicated significant treatment differences $(\mathrm{P} \leq$ $0.5)$. Data expressed as fold difference $\left(2^{(-\Delta \mathrm{Ct})}\right)$. 


\subsection{Effect of OVX on Transcript Abundance}

In PAR, FN and HSP 90 expression were down regulated $(\mathrm{P}=0.02$ and $\mathrm{P}=0.04$, respectively) while Epi was increased $(\mathrm{P}=0.003)$ in OVX relative to INT heifers (Figure 4(a)). In MFP (Figure 4(b)), Rac-1 and fascin were up regulated $(P=0.05)$. No other genes tested were affected by OVX in either PAR or MFP. Expression of $\mathrm{FN}$ in PAR was lower in $4 \mathrm{mo}$. relative to $2 \mathrm{mo}$. heifers $(\mathrm{P}=0.05)$. In MFP, ALD expression was reduced in $3 \mathrm{mo}$. compared with 2 mo. old heifers $(\mathrm{P}=0.05)$. Expression of Epi was less in 4 mo. compared with 2 mo. heifers ( $P$ $=0.02$ ). Expression of Tran was reduced in 3 mo. relative to 2 mo. heifers and greater in 4 mo. compared with 3 mo heifers $(P=0.02)$. Animals $3 \mathrm{mo}$. of age at surgery had decreased Tran expression in comparison to animals 2 and 4 mo. of age at surgery $(P=0.02)$. No other genes were affected by age or interaction between treatment and age.

\section{DISCUSSION}

This study is an extension of previous work that eval-

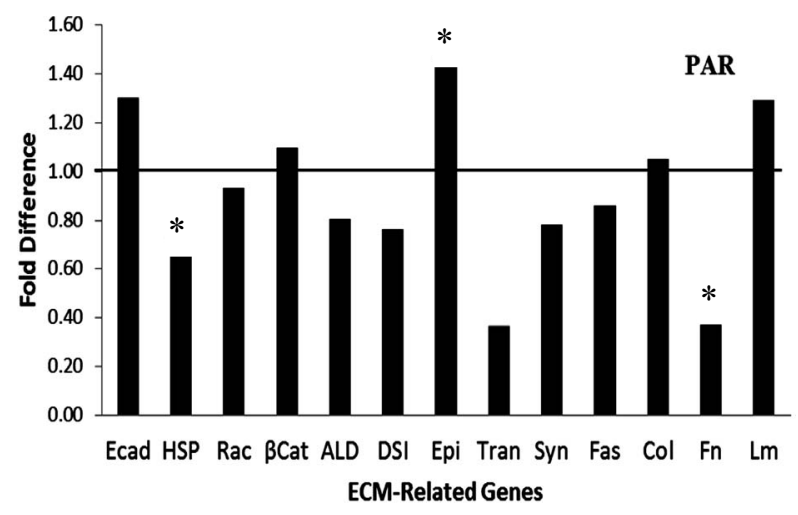

(a)

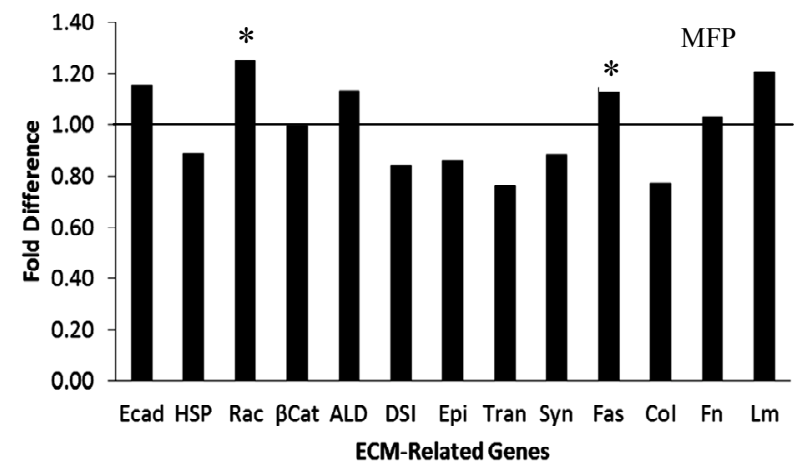

(b)

Figure 4. Gene expression for ECM-related genes in OVX and INT heifers. Gene expression for ECM-related genes in OVX heifers relative to INT treated heifers (represented by solid line at 1.00). Panel A provides data for parenchymal (PAR) tissue and panel B data for mammary fat pad (MFP). Asterisks $\left(^{*}\right)$ indicated significant treatment differences $(\mathrm{P} \leq 0.5)$. Data expressed as fold difference $\left(2^{(-\Delta \Delta \mathrm{Ct})}\right)$. uated the effect of exogenous GH (bST) (Huderson et al. [2]) and ovariectomy (Velayudhan et al. [3]) on mammary gland composition, proliferation and histology in prepubertal heifers. In contrast with work on older animals [25], we found that for these very young prepubertal heifers, exogenous GH had minimal impact on several measures of mammary development including: PAR mass, histological appearance and rate of cell proliferation (Huderson et al. [1]).

In contrast, ovariectomy of young prepubertal heifers decreased PAR accumulation and had an especially negative impact in heifers ovariectomized at the earliest age (Velayudhan et al. [2]). The relative change in PAR mass between 30 and 90 days of age is dramatic, approximately a 60-fold [8]. Consequently, we wanted to evaluate changes in the ECM to further understand these mammary growth and developmental responses. We measured the expression of selected ECM-related genes involved in cell proliferation, migration and morphogenesis in these heifers (Table 2). These genes were chosen because they were either shown to be perturbed by plane of nutrition (also known to impact prepubertal mammary development) or are involved in ECM action.

Expression of $\mathrm{FN}$, which functions in attaching ECM to the basement membrane and its integrin receptor, is both developmentally and hormonally regulated. Woodward et al. [26] showed that FN expression in mice increased 3 -fold in the first $10 \mathrm{wk}$ of life. Integrin $\alpha 5 \beta 1$ follows a similar pattern, increasing throughout early gestation with a sharp decrease in late gestation [26,27]. In the current study, we report significant decreases in FN mRNA expression in response to both exogenous bST and ovariectomy. This is surprising since in older heifers impaired mammary growth after ovariectomy was associated with increased expression of FN protein [18]. However, it is important to note that the current data reflect gene expression whereas Berry et al. [18] utilized western blotting and immunocytochemistry to evaluation the appearance of FN in mammary tissue homogenates and in tissue sections. We have also shown that proliferation of bovine mammary epithelial cells in response to IGF-I is reduced in cells incubated on FN coated tissue culture dishes (unpublished data).

Growth factors such as IGF-I are involved in complex regulatory partnerships with the ECM. Growth factors are not only capable of binding the ECM directly but can also induce synthesis and secretion of select ECM molecules which impact growth factor signaling [29]. In the murine mammary gland IGF-I and EGF act synergistically to enhance epithelial cell proliferation. This synergistic effect is attributed to IGF-I up regulation of EGF receptor expression [26]. In return EGF dampens the inhibitory effects of IGF-I binding proteins (IGFBP) 2 and 3. Expression of IGFBP 2 and 3 is also attenuated in cells cultured on FN [26]. 
Table 2. Target ECM-related genes and cellular function ${ }^{1,2}$.

\begin{tabular}{|c|c|c|}
\hline Gene Name & Proposed Function & Reference \\
\hline Ecadherin & Cellular adhesion & Woodward et al. [16] \\
\hline Heat Shock Protein 90 & Regulation of steroid hormone receptors & Echeverria et al. [35] \\
\hline Rac-1 & $\begin{array}{l}\text { Transmitter of ECM signals affecting proliferation; } \\
\text { regulator of morphogenesis }\end{array}$ & Ewald et al. [39] \\
\hline$\beta$-catenin & Formation of cadherin-containing cell-cell junctions & Teuliere et al. $[46]$ \\
\hline Aldehyde dehydrogenase $1 \mathrm{~A} 1^{\mathrm{a}}$ & $\begin{array}{l}\text { Enzymatically converts vitamin A into retinoic acid; retinoic } \\
\text { acid is an inhibitor of IGF-1 stimulated proliferation. }\end{array}$ & Daniels et al. [47] \\
\hline Protein disulfide isomerase $^{a}$ & $\begin{array}{l}\text { Cell surface protein maturation; Activation/regulation cell signaling } \\
\text { pathway }\end{array}$ & Daniels et al. [47] \\
\hline Epimorphin & Key promoter of morphogenesis & Hirai et al. [32] \\
\hline Transferrin $^{\mathrm{a}}$ & Tight binder of iron; also shown to bind IGFBP-3 & Daniels et al. [47] \\
\hline Syndecan & $\begin{array}{l}\text { Mediate cell-cell adhesion and growth factor actions } \\
\text { (i.e. fiberblast growth factor) }\end{array}$ & Bernfield et al. [48] \\
\hline Fascin $^{\mathrm{a}}$ & $\begin{array}{l}\text { Forms complex with } \beta \text {-catenin to attach cadherins to the } \\
\text { cytoskeleton of cells; aids in cell migration }\end{array}$ & Guvakova et al. [49] \\
\hline Collagen I & Most abundant protein; promotes proliferation; direct development & Berry et al. [18] \\
\hline Fibronectin & $\begin{array}{l}\text { Aids in the stability of the ECM by providing attachment } \\
\text { for both cells and other ECM components }\end{array}$ & Berry et al. [18] \\
\hline Laminin & Major component in the basal lamina and aids in cell attachment & Berry et al. [18] \\
\hline
\end{tabular}

${ }^{1}$ ECM-related genes were chosen based on previous data showing response or a role in proliferation and maturation in the mammary gland. ${ }^{2}$ Genes previously shown to be modified by plane of nutrition (Daniels et al. [47]).

In contrast with older heifers, removal of ovarian hormones by ovariectomy in sexually mature mice produced a reversible decrease in $\mathrm{FN}$ and integrin $\alpha 5 \beta 1$ expression [26,27]. Thus, $\mathrm{FN}$ and $\alpha 5 \beta 1$ can mediate hormonal and growth factor effects on the mammary gland. In mouse mammary epithelial cells, DNA synthesis and retention of estrogen receptor (ER) are increased when these cells are cultured on FN in the presence of progesterone. Additionally, a proliferative response to progesterone was only observed when cells were cultured, serum-free, on FN [26]. In our calves, we noted the absence (immunocytochemical staining) of the progesterone receptor (PR) in epithelial cells of ovariectomized heifers (Velayudhan, unpublished). It may be that modulation of FN expression acts to also alter PR expression. Fibronectin and $\alpha 5 \beta 1$ is maximal at times of E- and P-dependent proliferation in the mammary gland [30]. It may be that ovariectomy abolished E-induced FN expression and thus PR induction.

In addition to reducing expression of $\mathrm{FN}$, ovariectomy increased Epi, and decreased heat shock protein 90 in PAR. In the MFP, ovariectomy increased expression of Rac and fascin. A plasma membrane anchored protein, Epi influences epithelial morphogenesis in multiple tissues [31]. In virgin mice Epi is localized to stromal fibroblasts and myoepithelial cells. It also surrounds many ducts [31,32]. The functions of Epi are presentation-de- pendent. When presented to the periphery of epithelial cells, Epi stimulates the organization of a lumen and side branching in epithelial cells, however, if presented to the entire cell Epi stimulates radial growth and the cells organize into spheres [32]. In ovariectomized heifers, Epi expression was increased in PAR. In normal development, the presence of Epi primes cells to undergo morphogenesis in the presence of growth factors while simultaneously inhibiting proliferation [32]. This suggests that increased Epi expression could explain the dramatic impairments in ductular development that occurs in older ovariectomized heifers [28]. We also noted (Velayudhan et al. [2]) that epithelial cell stratification in mammary ducts was reduced in ovariectomized calves in this trial.

Safayi et al. [33] evaluated the ontogeny of myoepithelial cell differential markers in prepubertal heifer calves that were ovariectomized (or sham operated) at 40 days of age then tissues were collected at 15 to 30 days intervals to 160 days of age. Ovariectomy altered the expression of both CD10 and smooth muscle actin in myoepithelial cells as well as myoepithelial cell development. In ovariectomized animals myoepithelial cells were smaller, irregular and generally flattened. Highly arborescent ductal structures were common in intact heifers but rare in ovariectomized animals. Given myoepithelial cells are known to limit parenchymal growth in 
some species [34], it may be that Epi expression is involved in modified myoepithelial cell development and associated impaired ductal development following ovariectomy.

The reduction in HSP 90 noted in PAR of ovariectomized heifers corresponds with the reduction in mammary PAR mass and reduced expression of PCNA reported previously (Velayudhan et al. [2]. It is well established that HSP 90 and related proteins are important in the formation and stabilization of estrogen receptor dimers and overall steroid hormone signaling [35,36]. Indeed, there is much current work to target HSP 90 and related molecules as tools to reduce tumor cell proliferation [37].

A small Rho-GTPase, Rac-1 regulates morphogenesis and mediates hormonal and ECM signals to alter cellular polarity [38,39]. Additionally, Rac-1 is involved in multiple signaling pathways and functions as a transcriptional regulator [40]. In this study ovariectomy increased Rac-1 mRNA expression in MFP. Ovariectomized spontaneously hypertensive mice also show increased vascular Rac mRNA that is reversed with E treatment [41]. Ovariectomy induces similar effects in monocytes [42]. A direct impact of altered Rac expression in mammary fat pad on epithelial cell proliferation, which is located several millimeters away, is difficult to explain. However, indirect effects via Rac-1 activity in MFP fibroblasts or adipocytes, and associated cell cross-talk are a possibility.

Similarly, it is difficult to relate increased fascin expression in the MFP after ovariectomy with alterations in mammary parenchymal development. Fascin is typically overexpressed in carcinomas and linked to increased metastasis. It is thought that this actin bundling protein alters cell shape and propensity for cell migration. Sun et al. [43] describe a role for TGF $\beta$ induced fascin expression and changes in tumor microenvironment to allow for enhanced invasion. It may be that changes in MFP fascin, as with Rac-1, reflect altered stromal cell activity but not parenchymal development directly.

In our current study, the ovary was a more potent regulator of mammary gland ECM-related genes than administration of exogenous GH. However, this should not be taken as evidence that GH secretion has no effect. A more likely conclusion is that supplying extra GH at this time had minimal impact on expression of the ECM-related genes that were evaluated. Furthermore, ovariectomy decreased proliferation of epithelial cells and increased the expression of genes involved in morphogenesis. Exogenous GH caused minimal changes in PAR and had no effect on MFP. In GH treated animals, ECM regulation appeared to be temporal, which when examined closer is in agreement with previous studies which show that GH concentrations increase with age [25]. It is plausible that while we saw no acute effects of exogenous GH, these glands were "primed" and that the effects of the exogenous GH may become evident in subsequent development. Interestingly, preliminary data from our lab have detected the presence of the androgen converting enzyme aromatase in mammary tissue (Huderson, unpublished). Initial evaluation suggests that expression of aromatase was not altered by either exogenous GH or ovariectomy. It is possible that local production of $\mathrm{E}$ may have compensated for the presumptive removal of ovarian E, thus reducing the effects of ovariectomy and minimized effects associated with exogenous GH. To determine if impacts of ovariectomy are specifically $\mathrm{E}$ mediated, experiments in which prepubertal heifers are treated with an anti-estrogen will be needed. In this study, we show modulation of mammary gland development by ovariectomy but we cannot definitively determine that effects are strictly due to absence or reduction in $\mathrm{E}$.

In summary, we have only begun to characterize the molecular events involved in the alteration of the ECM microenvironment. Future studies investigating integrin and mammary metalloproteinase expression are still needed to better understand the mechanism behind ovarian regulation of mammary development especially in very young prepubertal heifers.

\section{ACKNOWLEDGEMENTS}

The authors thank Cathy Parsons (Virginia Tech) for technical support. These studies were supported by National Research Initiative Competitive grant no. 2006-35206-166699, "Ovarian Regulation of Stem Cells and IGF-I Axis Molecules in Prepubertal Heifer Mammary Gland to R.M. Akers and S.E. Ellis as well as a grant from Monsanto Company ( St. Louis, MO; 2006 07-0247-08) to R. M. Akers.

\section{REFERENCES}

[1] Tucker, H.A. (1981) Physiological control of mammary growth, lactogenesis, and lactation. Journal of Dairy Science, 64, 1403-1421. doi:10.3168/jds.S0022-0302(81)82711-7

[2] Huderson, B.P., Velayudhan, B.T., Pearson, R.E., Ellis, S.E. and Akers, R.M. (2011) Effects of Exogenous somatotropin in Holstein calves on mammary gland composition and proliferation. Journal of Dairy Science, 94, 5005-5016. doi:10.3168/jds.2011-4229

[3] Velayudhan, B.T., Huderson B.P., McGilliard, M.L., Jiang, H., Ellis, S.E and Akers, R.M. (2012) Effect of staged ovariectomy on measures of mammary growth and development in prepubertal dairy heifers. Animal, 6, 941-951. doi:10.1017/S1751731111002333

[4] McFadden, T.B., Daniel, T.E. and Akers, R.M. (1990) Effects of plane of nutrition, growth hormone and unsaturated fat on growth hormone, insulin and prolactin receptors in prepubertal lambs. Journal of Animal Science, 68, 3180-3189. 
[5] Sinowatz, F., Schams, D., Kolle, S., Plath, A., Lincoln, D. and Waters, M. J. (2000) Cellular localisation of GH receptor in the bovine mammary gland during mammogenesis, lactation and involution. Journal of Endocrinology, 166, 503-510. doi:10.1677/joe. 0.1660503

[6] Plath-Gabler, A., Gabler, C., Sinowatz, F., Berisha B. and Schams, D. (2001) The expression of the IGF family and $\mathrm{GH}$ receptor in the bovine mammary gland. Journal of Endocrinology, 168, 39-48. doi:10.1677/joe.0.1680039

[7] Akers, R.M., McFadden, T.B., Purup, S., Vestergaard, M., Sejrsen, K. and Capuco, A.V. (2000) Local IGF-I axis in peripubertal ruminant mammary development. Journal of Mammary Gland Biology and Neoplasia, 5, 43-51. doi:10.1023/A:1009563115612

[8] Akers, R.M., Ellis, S.E. and Berry, S.D. (2005) Ovarian and IGF-I axis control of mammary development in prepubertal heifers. Domestic Animal Endocrinology, 29, 259-267. doi:10.1016/j.domaniend.2005.02.037

[9] Woodward, T.L., Beal, W.E. and Akers, R.M. (1993) Cell interactions in initiation of mammary epithelial proliferation by oestradiol and progesterone in prepubertal heifers. Journal of Endocrinology, 136, 149-157. doi:10.1677/joe.0.1360149

[10] Berry, S.D., McFadden, T.B., Pearson, R.E. and Akers, R.M. (2001) A local increase in the mammary IGF-1: IGFBP-3 ratio mediates the mammogenic effects of estrogen and growth hormone. Domestic Animal Endocrinology, 21, 39-53. doi:10.1016/S0739-7240(01)00101-1

[11] Berry, S.D., Jobst, P.M., Ellis, S.E., Howard, R.D., Capuco, A.V. and Akers, R.M. (2003c) Mammary epithetlial proliferation and estrogen receptor alpha expression in prepubertal heifers: Effects of ovariectomy and growth hormone. Journal of Dairy Science, 86, 2098-2105. doi:10.3168/jds.S0022-0302(03)73799-0

[12] Capuco, A.V., Ellis, S.E., Wood, D. L., Akers, R.M., Garrett, W. (2002) Postnatal mammary ductal growth: Threedimensional imaging of cell proliferation, effects of estrogen treatment, and expression of steroid receptors in prepubertal calves. Tissue and Cell, 34, 143-154. doi:10.1016/S0040-8166(02)00024-1

[13] Meyer, M.J., Capuco, A.V., Ross, D.A., Lintault, L.M. and Van Amburgh, M.E. (2006) Developmental and nutritional regulation of the prepubertal heifer mammary gland: I. Parenchyma and fat pad mass and composition. Journal of Dairy Science, 89, 4289-4297. doi:10.3168/jds.S0022-0302(06)72475-4

[14] Sinha, Y.N. and Tucker, H.A. (1969) Mammary development and pituitary prolactin level of heifers from birth through puberty and during the estrous cycle. Journal of Dairy Science, 52, 507-512. doi:10.3168/jds.S0022-0302(69)86595-1

[15] Xu, R., Boudreau A. and Bissell, M.J. (2009) Tissue architecture and function: Dynamic reciprocity via extra and intra-cellular matrices. Cancer and Metastasis Reviews, 28, 167-176. doi:10.1007/s10555-008-9178-Z

[16] Woodward, T.L., Xie, J., Fendrick, J.L. and Haslam, S.Z. (2000) Proliferation of mouse mammary epithelial cells in vitro: Interactions among epidermal growth factor, insulin-like growth factor I, ovarian hormones, and extra- cellular matrix proteins. Endocrinology, 141, 3578-3586. doi:10.1210/en.141.10.3578

[17] Xie, J. and Haslam, S.Z. (1997) Extracellular matrix regulates ovarian hormone-dependent proliferation of mouse mammary epithelial cells. Endocrinology, 138, 24662473. doi:10.1210/en.138.6.2466

[18] Berry, S.D., Howard, R.D. and Akers R.M. (2003) Mammary localization and abundance of laminin, fibronectin, and collagen IV proteins in prepubertal heifers. Journal of Dairy Science, 86, 2864-2874. doi:10.3168/jds.S0022-0302(03)73883-1

[19] Rabot, A., Sinowatz, F., Berisha, B., Meyer, H.H.D. and Schams, D. (2007) Expression and localization of extracellular matrix-degrading proteinases and their inhibittors in the bovine mammary gland during development, function, and involution. Journal of Dairy Science, 90, 740-748. doi:10.3168/jds.S0022-0302(07)71558-8

[20] Casey, T., Dover, H., Liesman, J., DeVries, L., Kupel, M., VanderHaar, M. and Plaut, K. (2011) Transcriptome analysis of epithelial and stromal contributions to mammogenesis in three week prepartum cows. PLOS ONE, 6, e2241. doi:10.1371/journal.pone.0022541

[21] Hovey, R. and Aimo, L. (2010) Diverse and active roles for adipocytes during mammary gland growth and function. Journal of Mammary Gland Biology and Neoplasia, 15, 279-290. doi:10.1007/s10911-010-9187-8

[22] Su, Y., Shankar, K., Rahal, O. and Simmen, R.C.M. (2011) Bidirectional signaling of mammary epithelium and stroma: Implications for breast cancer-Preventive actions of dietary factors. The Journal of Nutritional Biochemistry, 22, 605-611. doi:10.1016/j.jnutbio.2010.09.008

[23] Maller, O., Martinson, H. and Schedin, P. (2010) Extracellular matrix composition reveals complex and dynamic stromal-epithelial interactions in the mammary gland. Journal of Mammary Gland Biology and Neoplasia, 15, 301-318. doi:10.1007/s10911-010-9189-6

[24] Piantoni, P., Bionaz, M., Graugnard, D.E., Daniels, K.M., Akers, R.M. and Loor, J.J. (2008) Gene expression ratio stability evaluation in prepubertal bovine mammary tissue from calves fed different milk replacers reveals novel internal controls for quantitative polymerase chain reaction. Journal of Nutrition, 138, 1158-1164.

[25] Purup, S., Sejrsen, K., Foldager, J. and Akers, R.M. (1993) Effect of exogenous bovine growth hormone and ovariectomy on prepubertal mammary growth, serum hormones and acute in-vitro proliferative response of mammary explants from Holstein heifers. Journal of Endocrinology, 139, 19-26. doi:10.1677/joe.0.1390019

[26] Woodward, T.L., Mienaltowski, A.S., Modi, R.R., Bennett, J.M. and Haslam, S.Z. (2001) Fibronectin and the alpha(5)beta(1) integrin are under developmental and ovarian steroid regulation in the normal mouse mammary gland. Endocrinology, 142, 3214-3222. doi:10.1210/en.142.7.3214

[27] Haslam, S.Z. and Woodward, T.L. (2001) Reciprocal regulation of extracellular matrix proteins and ovarian steroid activity in the mammary gland. Breast Cancer Research, 3, 365-372. doi:10.1186/bcr324 
[28] Berry, S.D., Howard, R.D., Jobst, P.M., Jiang, H. and Akers R.M. (2003) Interactions between the ovary and the local IGF-I axis modulate mammary development in prepubertal heifers. Journal of Endocrinology, 177, 295304. doi:10.1677/joe. 0.1770295

[29] Hansen, R.K. and Bissell, M.J. (2000) Tissue architecture and breast cancer: The role of extracellular matrix and steroid hormones. Endocrine-Related Cancer, 7, 95113. doi:10.1677/erc.0.0070095

[30] Ferguson, J.E., Schor, A.M., Howell A. and Ferguson M.W. (1992) Changes in the extracellular matrix of the normal human breast during the menstrual cycle. Cell and Tissue Research, 268, 167-177. doi:10.1007/BF00338066

[31] Bascom, J.L., Fata, J.E., Hirai, Y., Sternlicht, M.D. and Bissell, M.J. (2005) Epimorphin overexpression in the mouse mammary gland promotes alveolar hyperplasia and mammary adenocarcinoma. Cancer Research, 65, 8617-8621. doi:10.1158/0008-5472.CAN-05-1985

[32] Hirai, Y., Lochter, A., Galosy, S., Koshida, S., Niwa, S. and Bissell, M.J. (1998) Epimorphin functions as a key morphoregulator for mammary epithelial cells. The Journal of Cell Biology, 140, 159-169.

doi:10.1083/jcb.140.1.159

[33] Safayi, S., Korn, N., Bertram, A., Akers, R.M., Capuco, A.V., Pratt, S.L. and Ellis, S. (2012) Myoepithelial cell differentiation markers in prepubertal bovine mammary gland: Effect of ovariectomy. Journal of Dairy Science, 95, 2965-2976. doi:10.3168/jds.2011-4690

[34] Gudjonsson, T., Adriance, M.C., Sternlicht, M.D. Petersen, O.W. and Bissell, M.J. (2005) Myoepithelial cells: Their origin and function in breast morphogenesis and neoplasia. Journal of Mammary Gland Biology and Neoplasia, 10, 261-272. doi:10.1007/s10911-005-9586-4

[35] Echeverria, P.C. and Picard, D. (2010) Molecular chaperones, essential partners of steroid hormone receptors for activity and mobility. Biochemica Biophysica Acta, 1803, 641-649. doi:10.1016/j.bbamcr.2009.11.012

[36] Sanchez, E.R. (2012) Chaperoning steroidal physiology: Lessons from mouse genetic models of Hsp90 and its cochaperones. Biochimica Biophysica Acta, 1823, 722-729. doi:10.1016/j.bbamcr.2011.11.006

[37] Diehl, M.C., Idowu, M.O., Kimmelshue, K., York, T.P., Elmore L.W. and Holt, S.E. (2009) Elevated expression of nuclear Hsp90 in invasive breast tumors. Cancer Biology \& Therapy, 8, 1952-1961. doi:10.4161/cbt.8.20.9639

[38] ] Keely, P.J., Westwick, J.K., Whitehead, I.P., Der, C.J. and Parise L.V. (1997) Cdc42 and Rac1 induce integrinmediated cell motility and invasiveness through $\mathrm{PI}(3) \mathrm{K}$. Nature, 390, 632-636. doi:10.1038/37656

[39] Ewald, A.J., Brenot, A., Duong, M., Chan, B.S. and Werb, Z. (2008) Collective epithelial migration and cell rearrangements drive mammary branching morphogenesis. Developmental Cell, 14, 570-581.

\section{doi:10.1016/j.devcel.2008.03.003}

[40] Su, L.F., Knoblauch, R. and Garabedian, M.J. (2001) Rho GTPases as modulators of the estrogen receptor transcriptional response. The Journal of Biological Chemistry, 276, 3231-3237. doi:10.1074/jbc.M005547200

[41] Laufs, U., Adam, O., Strehlow, K., Wassmann, S., Konkol, C., Laufs, K., Schmidt, W., Bohm, M. and Nickenig, G., (2003) Down-regulation of Rac-1 GTPase by Estrogen. The Journal of Biological Chemistry, 278, 5956-5962. doi:10.1074/jbc.M209813200

[42] Adam, O., Hagel, M., Theobald, K., Bohm, M. and Laufs, U. (2009) Inhibitory effect of estrogen on Rac1-expression in monocytes. Biochemical and Biophysical Research Communications, 386, 45-49. doi:10.1016/j.bbrc.2009.05.126

[43] Sun, J., He, H., Xiong, Y., Lu, S., Shen, J., Cheng, A., Chang, W., Hou, M., Lancaster, J.M., Kim, M. and Yang, S. (2012) Fascin protein is critical for transforming growth factor $\beta$ protein-induced invasion and filopodia formation in spindle-shaped tumor cells. The Journal of Biological Chemistry, 286, 38865-38875. doi:10.1074/jbc.M111.270413

[44] Nicodemus, G.D., Villanueva, I. and Bryant, S.J. (2007) Mechanical stimulation of TMJ condylar chondrocytes encapsulated in PEG hydrogels. Journal of Biomedical Materials Research, 83, 323-331. doi:10.1002/jbm.a.31251

[45] Musters, S., Coughlan, K., McFadden, T., Maple, R., Mulvey, T. and Plaut, K. (2004) Exogenous TGF-beta1 promotes stromal development in the heifer mammary gland. Journal of Dairy Science, 87, 896-904. doi:10.3168/jds.S0022-0302(04)73234-8

[46] Teuliere, J., Faraldo, M.M., Deugnier, M.A., Shtutman, M., Ben-Ze'ev, A., Thiery, J.P. and Glukhova, M.A. (2005) Targeted activation of beta-catenin signaling in basal mammary epithelial cells affects mammary development and leads to hyperplasia. Development, 132, 267-277. doi:10.1242/dev.01583

[47] ] Daniels, K.M., Webb Jr., K.E., McGilliard, M.L., Meter, M.J., Amburgh, M.E. and Akers, R.M. (2006) Effects of body weight and nutrition on mammary protein expression profiles in Holstein heifers. Journal of Dairy Science, 89, 4276-4288. doi:10.3168/jds.S0022-0302(06)72474-2

[48] Bernfield, M., Gotte, M., Park, P.W., Reizes, O., Fitzgerald, M.L., Lincecum, J. and Zako, M. (1999) Functions of cell surface heparan sulfate proteoglycans. Annual Review of Biochemistry, 68, 729-777. doi:10.1146/annurev.biochem.68.1.729

[49] Guvakova, A., Boettiger, D. and Adams, J.C. (2002) Induction of fascin spikes in breast cancer cells by activtion of the insulin-like growth factor-I receptor. The International Journal of Biochemistry \& Cell Biology, 34, 685-698. 